\title{
Chronic pain, fear of pain and movement avoidance belief
}

\section{Dor crônica e a crença de medo da dor e evitação ao movimento}

Dear collegues,

Chronic pain has beliefs that may influence pain magnitude, acceptance of pain, adherence to treatment and incapacity worsening. Among them, there are beliefs of healing, solicitude, self-efficacy when coping with pain, and fear of pain and movement avoidance ${ }^{1-5}$. Beliefs are pre-existing, stable and culturally learned notions about situations, events, people and ideas. The way in which we "understand" something and the meanings we attribute to it influence our emotions and behaviors with regard to such situations, ideas and people ${ }^{1,2}$.

Fear of movement is called kinesiophobia by some authors and is a situation where individuals develop exacerbated fear because they believe that movement is the cause of pain and of injury worsening, so they start avoiding movement and emphasizing immobility behaviors which result in further incapacity, dependence and disuse ${ }^{6}$.

Immobility in acute and chronic pain has different reasons. In acute pain, immobility aims at healing the injury, is temporary and adaptive. In chronic pain, immobility is not justified because very often there is no injury to heal, the painful condition is prolonged and immobility leads to further functional, emotional and social disorders.

Not all chronic pain individuals develop exacerbated fear of movement, and some may also deal with pain and physical activity in an adaptive manner. If painful experience is not perceived as a threat, it may be faced by the individual. There is maladaptive coping when, after an injury and painful experience, catastrophic thoughts lead to fear of pain, to movement avoidance behaviors, to decreased daily activities and increased dependence. If movement avoidance behaviors become persistent, there are musculoskeletal system problems, disuse syndrome, fatigue, anxiety and hypervigilance, depression and worsening of pain. Patients enter a vicious cycle where the higher the fear of pain, the higher the hypervigilance and movement avoidance 7 .

The adjustment of fear of pain and movement avoidance belief aiming at eliminating immobility behaviors requires educative actions, specific strategies to measure and redefine such belief and the use of live exposure and gradual activity techniques, among other possibilities. The purpose is that patients deconstruct preconceived ideas, expose themselves to "prohibited" exercises, notice that fear of pain and immobility is exaggerated and that movement is not related to chronic pain worsening ${ }^{8,9}$.

In Brazil, experiences exploring all these interventions are still scarce and, considering that such strategies have been very useful worldwide, it is desirable to have more studies in this area in Brazil. It is with great pleasure that we see in this edition two studies addressing the problem caused by kinesiophobia.

Yours truly,

Érica Brandão de Moraes

Doctorate student of the School of Nursing, University of São Paulo

Cibele Andrucioli de Mattos Pimenta

Head professor of the School of Nursing, University of São Paulo, Coordinator of the CNPq research group "Pain, symptoms control and palliative care".

\section{REFERENCES}

1. Pimenta CA, da Cruz DA. Crenças em dor crônica: validação do inventário de atitudes frente à dor para a lingua portuguesa. Rev Esc Enferm USP. $2006 ; 40$ (3):365-73.

2. Sardá Junior J, Nicholas MK, Pereira IA, Pimenta CA, Asghari A, Cruz RM. Validação da escala de pensamentos catastróficos sobre dor. Acta Fisiatr. 2008;15(1):31-6.

3. Tait RC, Chibnall JT. Development of a brief version of the Survey of Pain Attitudes. Pain. 1997;70(2-3):229-35

4. Jensen MP. Control beliefs, coping efforts, and adjustment to chronic pain. J Consult Clin Psychol. 1991;59(3):431-8.

5. Salvetti MG, Pimenta CA, Braga PE, Corrêa CF. Incapacidade relacionada à dor lombar crônica: prevalência e fatores associados. Rev Esc Enferm USP. 2012;46(Esp):16-23.

6. de Moraes Vieira EB, de Góes Salvetti M, Damiani LP, de Mattos Pimenta CA. Self-efficacy and fear avoidance beliefs in chronic low back pain patients: coexistence and associated factors. Pain Manag Nurs. 2014 [Epub ahead of print].

7. Vlaeyen JW, Linton SJ. Fear-avoidance and its consequences in chronic musculoskeletal pain: a state of the art. Pain. 2000;85(3):317-32.

8. Vlaeyen JW, Linton SJ. Fear-avoidance model of chronic musculoskeletal pain: 12 years on. Pain. 2012;153(6):1144-7.

9. Henschke N, Ostelo RW, van Tulder MW, Vlaeyen JW, Morley S, Assendelft WJ, Main CJ. Behavioural treatment for chronic low-back pain. Cochrane Database Syst Rev. 2010;(7):CD002014. 